\title{
Alergi Makanan pada Bayi dan Anak
}

\author{
Sjawitri P Siregar
}

\begin{abstract}
Alergi makanan sebagian besar didasari reaksi hipersensitivitas tipe I. Gejala tersering pada organ saluran napas, saluran cerna, kulit dan sistemik berupa anafilaksis. Pemeriksaan uji kulit + terhadap makanan harus dilanjutkan dengan uji eliminasi dan provokasi (baku linar). Alergi makanan lebih sering terjadi pada usia tahun pertama kehidupan dan 2/3 akan toleran setelah eliminasi selama 1-2 tahun.
\end{abstract}

Kata kunci: DBPCFC (double blind placebo controle food challenge), FEIA CAP-RAST (fluoresense enzyme immunoassay radioallergo sorbent test), IgE RAST (Imunoglobulin E radio allegro sorbent test)

$\mathcal{K}$ urang lebih $15 \%$ dari masyarakat menduga bahwa mereka alergi terhadap salah satu makanan, padahal angka kejadian alergi makanan pada anak berkisar 6-8\% sedangkan pada dewasa $1-2 \% .{ }^{1}$ Ini disebabkan karena istilah alergi makanan sering dipakai dalam arti yang salah atau kurang tepat. The American of Allergy and Immunology and the National Institute of Allergy and Infectious Diseases (National Institutes of Health=NIH) menetapkan beberapa istilah. Reaksi yang tidak diinginkan terhadap makanan, disebut juga reaksi simpang makanan (adverse food reaction) adalah istilah umum yang dipakai untuk menyatakan reaksi yang timbul setelah memakan sesuatu makanan. Reaksi alergi makanan adalah reaksi simpang makanan akibat respons imunologik yang abnormal, sedangkan intoleransi makanan akibat mekanisme non imunologis. ${ }^{1}$

Sebagian besar alergi makanan dasarnya reaksi hipersensitivitas tipe I yang diperankan oleh antibodi IgE spesifik. Reaksi alergi makanan dapat juga didasari oleh non IgE, seperti pada trombositopenia akibat alergi susu sapi yang diperankan oleh reaksi antigenantibody-dependent cytotoxic (reaksi hipersensitivitas

Alamat korespondensi:

Dr. Sjawitri P. Siregar, Sp.A(K).

Subbagian Alergi Imunologi Klinik. Bagian Ilmu Kesehatan Anak FKUI RSCM, Jakarta. Jl. Salemba No. 6, Jakarta 10430.

Telepon 021-316 1144. Fax. 021-390 7743. tipe II), dan reaksi kompleks antigen antibodi (reaksi hipersensitivitas tipe III) dan reaksi imunologik lain seperti terdapat anti IgA gliadin antibodi pada penyakit Celiac. Reaksi hipersensitivitas tipe lambat (reaksi hipersensitivitas tipe IV) gejalanya timbul setelah beberapa jam sampai beberapa hari kemudian dan sering memberikan gejala pada saluran cerna. Sampai sekarang sulit membuktikan patogenesis alergi makanan yang disebabkan hipersensitivitas tipe II dan tipe III. Diperkirakan sebagian besar alergi makanan didasari oleh reaksi hipersensitivitas tipe I yang diperankan oleh $\operatorname{IgE}$ dan reaksi hipersensitivitas tipe IV atau kombinasi dari keduanya. ${ }^{2,3}$

Sebagian besar reaksi simpang makanan tergolong intoleransi makanan. Contohnya kontaminasi toksik histamin yang dihasilkan ikan, toksin dari Salmonella atau Shigella, reaksi farmakologis terhadap kafein dalam kopi, tiramin dari keju, reaksi metabolik pada defisiensi enzim laktase dan reaksi idiosinkrasi akibat gangguan psikis

Ternyata reaksi alergi makanan lebih sering terjadi pada usia tahun pertama kehidupan seorang anak. Di Poliklinik Alergi Imunologi Bagian Ilmu Kesehatan Anak RS Cipto Mangunkusumo terdapat 4,6\% alergi makanan selama kurun waktu 9 tahun (1987-1996). ${ }^{4}$ Dan selama setahun (1996-1997) dari 18 anak alergi susu sapi, 13 di antaranya berusia di bawah 1 tahun. ${ }^{5}$ Pada tulisan ini akan dibahas diagnosis dan tatalaksana alergi makanan. 


\section{Alergen Makanan}

Makanan antara lain terdiri dari lemak, karbohidrat dan protein. Bahan makanan yang sering bersifat alergen adalah glikoprotein yang larut dalam air dengan berat molekul antara 10.000 - 60.000 Dalton. Umumnya alergen ini stabil pada pemanasan, tahan terhadap asam dan enzim protease. Jadi hanya sebagian kecil saja makanan yang dilaporkan bersifat alergen yang dapat memberikan reaksi alergi makanan; misalnya susu sapi, telur, kacang, ikan, kacang kedele, dan gandum (Tabel 1). Susu sapi terdiri dari kurang lebih 25 macam protein yang memproduksi antibodi spesifik pada manusia. Antigen yang tersering pada susu sapi adalah casein dan whey. Whey terdiri dari blaktoglobulin, a-laktalbumin, bovin serum albumin dan bovin gamaglobulin.

Alergen dalam jumlah sedikitpun dapat mensensitisasi dan menimbulkan gejala pada individu atopik. Beberapa mikrogram alergen inhalan dapat

Tabel 1. Antigen Makanan

\begin{tabular}{lll}
\hline Fraksi protein & $\begin{array}{l}\text { Prosentase } \\
\text { protein makanan }\end{array}$ & Berat molekul \\
\hline $\begin{array}{ll}\text { Susu sapi } \\
\quad \text { Casein }\end{array}$ & $76-86$ & $19000-24000$ \\
$\quad$ Whey & & \\
$\begin{array}{l}\text { B-Laktoglobulin } \\
\text { Q-Laktalbumin }\end{array}$ & $7-12$ & 36000 \\
Putih telur & $2-5$ & 14400 \\
$\quad$ Ovomukoid & 11 & \\
$\quad$ Ovalbumin & 54 & 28000 \\
$\quad$ Ovotransferin & $12-13$ & 45000 \\
Kacang & & 77700 \\
$\quad$ Ara h1 & & 63500 \\
$\quad$ Ara h2 & & 17000 \\
$\quad$ Ara h3 & & 14000 \\
Kacang kedele & & \\
$\quad$ Inhibitor tripsin & & 20500 \\
$\quad$ Gly m1 & & 30000 \\
Ikan & \\
$\quad$ Gad m 1 & & 12328 \\
Udang & \\
Antigen 1 & & 42000 \\
Antigen II & & 38000 \\
Pen a 1 & & 36000 \\
\end{tabular}

Dikutip dari Sampson HA, $1997^{3}$ merangsang pembentukan IgE. Dalam hal makanan, tidak dapat diduga berapa banyak protein yang diserap dan berapa lama kontak dengan sistem imun serta berapa cepat alergen yang dimakan, dipecah untuk dapat diserap. Diperkirakan 1 mikrogram blaktoglobulin sudah dapat mensensitisasi. ${ }^{6}$ Sensitisasi makanan dapat juga melalui air susu ibu. ${ }^{7}$ Bahan penyedap dan zat warna juga dapat sebagai alergen misalnya aspartane (pemanis), zat warna kuning, merah, hijau, nitrit, monosodium glutamat, dan antioksidan.

\section{Patofisiologi}

\section{Peran $\lg \mathrm{E}$}

Kegagalan tubuh untuk dapat mentoleransi suatu makanan akan merangsang imunoglobulin $\mathrm{E}(\mathrm{IgE})$, yang mempunyai reseptor pada sel mast, basofil dan juga pada sel makrofag, monosit, limfosit, eosinofil dan trombosit dengan afinitas yang rendah. Ikatan IgE dan alergen makanan akan melepaskan mediator histamin, prostaglandin dan leukotrien dan akan menimbulkan vasodilatasi, kontraksi otot polos dan sekresi mukus yang akan menimbulkan gejala reaksi hipersensitivitas tipe I. Sel mast yang aktif akan melepaskan juga sitokin yang berperan pada reaksi hipersensitivitas tipe I yang lambat. Bila alergen dikonsumsi berulang kali, sel mononuklear akan dirangsang untuk memproduksi histamin releasing factor (HRF) yang sering terjadi pada seorang yang menderita dermatitis atopi. ${ }^{2}$

\section{Peran Non IgE}

Banyak dilaporkan bahwa mekanisme imun yang lain. (selain reaksi hipersensitivitas tipe I) dapat sebagai penyebab alergi makanan, namun bukti secara ilmiah sangat terbatas. Dilaporkan bahwa penelitian membuktikan reaksi hipersensitivitas tipe III berperan, tapi sedikit bukti yang menyokong penyakit kompleks imun antigen makanan. Reaksi hipersensitivitas tipe IV timbul beberapa jam kemudian, tetapi bukti yang pasti juga belum cukup.

\section{Manifestasi Klinis Alergi Makanan}

Manifestasi alergi makanan tipe IgE dapat bermacam- 
macam, tergantung dari tempat dan luas degranulasi sel mast, mulai dari urtikaria akut sampai reaksi anafilaksis yang fatal. ${ }^{3}$ Organ target yang sering terkena adalah kulit, saluran cerna, saluran napas atas, bawah dan sistemik.

Hill, dkk. ${ }^{7}$ membagi alergi susu sapi menjadi 3 kelompok yaitu:

- Kelompok I: Awitan timbul beberapa menit setelah memakan makanan yang jumlahnya sedikit. Gejala biasanya berupa urtikaria, angioedema, eksaserbasi eksema dan gejala saluran napas. Uji kulit positip, kadar IgE spesifik tinggi.

- Kelompok II: Awitan timbul beberapa jam setelah memakan makanan yang jumlahnya cukup banyak. Gejala pada saluran cerna berupa muntah dan diare. Uji kulit negatif dan kadar IgE spesifik negatif. Kelompok ini disebut intoleran protein susu sapi atau enteropati susu sapi.

- Kelompok III: Awitan timbul lebih lama sampai setelah 20 jam kemudian dan jumlah yang diminum sangat banyak. Gejala muntah, diare, gejala saluran napas dan eksaserbasi eksema. Uji kulit kadang dapat positif pada pasien dengan eksema kulit.

Kelompok di atas pada perjalanan penyakitnya dapat berubah, misalnya dari kelompok I menjadi kelompok II atau sebaliknya. Gejala alergi susu sapi di Sub-Bagian Alergi Imunologi Bagian Ilmu Kesehatan Anak terbanyak memberikan gejala batuk kronik berulang, diare, dermatitis atopik, rinitis alergi dan urtikaria. $^{5}$

\section{Kulit}

Urtikaria akut dan angioedema akibat kontak dan memakan sesuatu sering terjadi dan penyebabnya mudah diketahui, misalnya tangan seseorang menjadi bengkak dan gatal setelah mengupas udang atau bibir seorang anak bengkak setelah minum susu atau makan kacang. Sedangkan urtikaria menahun atau berulang alergennya sukar diketahui dan jarang disebabkan oleh reaksi hipersensitivitas tipe I saja, mungkin gabungan dengan reaksi hipersensitivitas tipe IV. Bruno ${ }^{6}$ mendapatkan dari 554 pasien urtikaria menahun hanya $1,4 \%$ disebabkan alergi makanan. ${ }^{6}$

Patogenesis dermatitis atopik (DA) pada anak masih belum diketahui dengan pasti apakah disebabkan oleh alergi makanan. Masih banyak kontroversi mengenai hal ini. ${ }^{7-9,10}$ Burks, dkk. melaporkan bahwa 33\% DA pada anak disebabkan alergi makanan yang dibuktikan dengan double blind placebo controle food challenge (DBPCFC). ${ }^{11}$ Sampson, dkk. ${ }^{3}$ membuktikan bahwa terdapat korelasi yang baik antara alergi makanan pada pasien DA yang dibuktikkan dengan cara DBPCFC dengan pemeriksaan IgE spesifik fluoresense enzyme immunoassay CAP-RAST (FEIA CAP-RAST). Dengan sistem ini didapat $1 / 3$ dari pasien DA sedang dan berat disebabkan oleh IgE mediated makanan, setelah diberikan diet eliminasi gejala DA membaik. Delapan puluh tujuh persen alergi makanan pada anak disebabkan oleh alergen telur, susu sapi, kacang, kacang kedele, dan gandum. ${ }^{8}$

Siregar, dkk. melaporkan bahwa pemberian telur pada usia di bawah 6 bulan pada pasien DA akan berisiko mendapatkan alergi respiratorik lebih besar daripada bila diberikan setelah usia 12 bulan. ${ }^{12}$ Seringkali dokter tidak memikirkan bahwa alergen makanan berperan pada penyakit DA. Jadi bila DA pada anak sukar diobati dengan pengobatan konvensional sebaiknya juga dicari kemungkinan penyebabnya alergen makanan.

\section{Saluran Cerna}

Alergi makanan dapat menimbulkaan gejala sistemik saluran cerna seperti nausea, muntah, diare, gembung, sering flatus, kolik dan konstipasi menahun. ${ }^{11}$ Sampsons mendapatkan 51\% pasien alergi makanan mempunyai gejala saluran cerna. ${ }^{3}$ Siregar, dkk. mendapatkan 5 dari 18 pasien alergi susu sapi mempunyai keluhan diare. ${ }^{12}$ Gejala di orofaring dapat timbul beberapa menit setelah memakan buah dan sayuran segar yang disebut sindrom alergi oral. ${ }^{6}$ Diperkirakan IgE memegang peranan pada penyakit gastroenteritis eosinofilik. Pada pasien dengan gastroentiritis eosinofilik terdapat gejala nausea, muntah, gagal tumbuh dan peningkatan eosinofil darah tepi dan pada biopsi saluran cerna tampak tumpukan infiltrasi sel eosinofil, dengan disertai intoleran berbagai 
makanan dan peningkatan kadar IgE disertai rinitis dan asma alergik.

\section{Saluran Napas}

Pasien asma yang disebabkan oleh alergi makanan umumnya terdapat pada anak usia muda dan sebagian besar didahului oleh dermatitis atopik. Dari 300 pasien asma yang berumur antara 7 bulan dan 80 tahun, terdapat alergi makanan pada 20 orang yang yang dibuktikan secara $D B P C F C$, dan hanya 6 orang yang memberikan hasil uji kulit positif atau IgE RAST. ${ }^{12}$

Gejala pada saluran napas berupa mengi, batuk dan sesak. Anak dengan DA disertai alergi makanan cenderung akan berkembang menjadi asma yang dicetuskan oleh makanan, dan sebagian besar akan menjadi asma menahun yang sukar di obati. Siregar, dkk. 1998 mendapatkan batuk kronik berulang pada 13 dari 18 anak dengan alergi susu sapi. ${ }^{12}$ Gejala batuk dan sesak napas dapat timbul setelah menghirup gandum yang dibakar disebut bakers asthma yang akan memberikan hasil kulit positip terhadap gandum.

\section{Rinitis Alergik}

Rinitis terdapat pada 70\% anak dengan alergi makanan yang dibuktikan dengan $D B P C F C$, dan sebagian besar juga menderita penyakit alergi lain, misalnya alergi pada kulit dan saluran cerna. Rinitis alergik lebih sering terjadi pada bayi dan anak. ${ }^{6}$

\section{Anafilaksis}

Terjadi dalam beberapa menit sampai 2 jam setelah mengkonsumsi makanan. Semua jenis makanan dapat menyebabkan reaksi anafilaksis, tetapi alergen tersering adalah kacang, tree nuts, ikan dan kerang. ${ }^{13}$ Gejala sistemik diikuti kelainan organ lain seperti kulit, saluran cerna dan saluran napas. Kadang kadang dapat terjadi kelainan kardiovaskular seperti hipotensi, aritmia dan renjatan. Pernah dilaporkan terjadi reaksi anafilaksis setelah memakan sesuatu yang diikuti olah raga dalam waktu 24 jam, sedangkan bila tidak diikuti olah raga, reaksi tidak terjadi. ${ }^{3}$ Spasme bronkus akibat alergi makanan pernah dilaporkan pada anak dengan asma yang berakibat fatal.

\section{Diagnosis}

Diagnosis alergi makanan ditegakkan berdasarkan pada anamnesis pemeriksaan fisis, dan pemeriksaan penunjang

\section{Anamnesis}

ditanyakan mengenai:

- Mengenal makanan yang dicurigai

- Jarak antara gejala yang timbul dan memakan makanan yang dicurigai

- Mengenal gejala yang ditimbulkan

- Jumlah makanan yang menimbulkan gejala Apakah gejala selalu timbul bila memakan makanan yang dicurigai?

- Berapa jarak waktu antara gejala terakhir dengan gejala yang baru timbul?

- Apakah ada faktor lain yang mempermudah timbulnya gejala misalnya setelah latihan olahraga

\section{Pemeriksaan fisik}

Apakah terdapat tanda dari penyakit atopi seperti kulit kering, bersisik, likenifikasi yang sering tampak pada pasien dermatitis atopik; allergic shiners, Siemen grease , mukosa hidung bengkak dan pucat yang sering tampak pada rinitis alergik; dan gejala mengi serta batuk berulang pada pasien asma. Juga penting menilai status gizi anak apakah sudah terjadi kurang gizi akibat diet yang diberikan

\section{Pemeriksaan penunjang}

a. Catatan buku harian pasien, untuk mencatat semua jenis makanan dan gejala yang timbul dalam jangka waktu tertentu

b. Uji kulit untuk menyaring apakah terdapat alergi makanan IgE mediated.

Beberapa hal harus diperhatikan pada uji kulit,

- Beberapa jenis makanan tidak dapat dilakukan uji kulit sebab tidak stabil misalnya buah, jeruk, pisang, pear, melon, kentang dan wortel.

- Anak di bawah usia 1 tahun sering memberikan hasil uji kulit negatip palsu, yang sebenarnya ia alergi makanan $\operatorname{IgE}$ mediated. Namun uji kulit makanan masih tetap diperlukan terutama pada anak di bawah umur 1 tahun. Bila hasil uji kulit positif, lebih mempunyai arti alergi makanan, karena kadar IgE nya yang masih rendah. ${ }^{14}$ 
- Anak di bawah usia 2 tahun mempunyai ukuran uji kulit lebih kecil.

- Hasil uji kulit terhadap makanan yang negatif berarti alergi makanan IgE mediated dapat disingkirkan (prediksi negatif akurasinya >95\%) sedangkan bila uji kulit terhadap makanan positif kemungkinan seorang memang alergi makanan IgE mediated hanya 50\% (prediksi positif akurasinya $<50 \%) .^{5}$

- Bila uji kulit negatip tetapi pada anamnesis dugaan kuat terhadap alergi suatu makanan pada sindrom oral alergi (oral allergy syndrome), dapat dilakukan uji dengan menggunakan zat makanan tersangka dalam bentuk segar, misalnya susu sapi langsung dari kartonnya, putih telur langsung dari telur segar langsung pada bibir dan mulutnya. ${ }^{6}$

- Uji kulit tidak dikerjakan pada pasien dengan reaksi anafilaksis.

- Uji kulit intradermal tidak dilakukan pada alergi makanan, disebabkan bahaya terjadinya reaksi anafilaksis

c. Provokasi double blind placebo control food challenge (DBPCFC) adalah pemeriksaan baku emas untuk menegakkan diagnosis alergi makanan. Provokasi makanan dapat dilakukan secara terbuka, single-blinded (pasien tidak mengetahui makanan yang diberikan), atau double-blinded (pasien, dokter dan stafnya tidak mengetahui makanan yang diberikan). Keuntungan pada double-blinded, dapat mengurangi angka positif palsu. Lima puluh persen uji provokasi terbuka yang memberikan hasil positif bila diulangi dengan cara $D B P C F C$ akan memberikan hasil negatif. Sebaliknya bila uji provokasi terbuka negatif akan memastikan bahwa alergi terhadap makanan tersebut dapat disingkirkan. Pada umumnya dikerjakan terlebih dahulu provokasi terbuka, bila hasilnya positif baru dilanjutkan dengan $D B P C F C$.

Bock dan Sampson melaporkan bahwa pada uji DBPCFC terdapat $1,8 \%$ dan $4,6 \%$ hasil negatif palsu disebabkan dosis yang kurang dan terdapat gejala kontak dermatitis, sedangkan hasil positif palsu sangat kecil 0,5-0,9\%. ${ }^{15}$ Pemilihan untuk melakukan provokasi terbuka atau tertutup tergantung dari beberapa faktor-klinis. Provokasi terbuka sebaiknya dilakukan pada makanan yang kemungkinan sangat kecil akan memberikan hasil positif misalnya uji kulit negatif dan pada anamnesis dugaan sangat kecil serta pada pasien yang uji kulit positif terhadap beberapa jenis makanan sedangkan anamnesis tidak menyokong. Pada provokasi terbuka, setiap bentuk makanan dapat diberikan asalkan dapat diukur jumlahnya. Dimulai dengan dosis sangat kecil dan dinaikkan bertahap sampai jumlah dosis yang memberikan gejala tercapai dalam waktu 1 jam. Pada anak kecil sebaiknya makanan tersebut berupa jus buah dengan rasa yang disenanginya. Provokasi secara DBPCFC sebaiknya dilakukan pada pasien yang sangat mungkin alergi terhadap makanan tersebut seperti pada telur, susu dan kacang, dengan uji kulit positif dan disertai dermatitis atopik. Pada provokasi $D B P C F C$ makanan tersangka dibuat bubuk dan dimasukkan ke dalam kapsul serta plasebo juga dimasukkan kedalam kapsul yang serupa.

\section{Persiapan untuk Provokasi Makanan}

- Penghindaran makanan tersangka minimal 2 minggu atau lebih.

- Penghindaran antihistamin.

- Penghindaran bonkodilator, cropmolyn, nedocromil dan steroid inhalasi 6-12 jam sebelum provokasi dilakukan.

- Tersedia obat untuk mengatasi reaksi anafilaksis yang mungkin akan timbul.

- Pasien dipuasakan 2-3 jam sebelum provokasi dilakukan.

- Dosis pertama harus lebih kecil dari dosis yang menyebabkan gejala alergi, maksimum 400mg.

- Dosis total 8-10gram dalam bentuk kering.

- Pasien harus diobservasi sampai 2 jam setelah diadakan provokasi.

d. Uji invitro untuk IgE mediated adalah Radio Alergo Sorbent Test (RAST), uji ini akan mendapatkan IgE spesifik makanan yang sangat berkorelasi dengan uji kulit. ${ }^{11}$ CAP sistim FEIA (Pharmacia \& Upjohn, Uppsala Sweden) dapat menentukan secara kuantitatif kadar makanan tersangka serta nilai positip dan negatipnya mempunyai nilai ketepatan lebih besar. Kadar IgE spesifik makanan berkorelasi dengan gejala klinis dan DBPCFC lebih dari 95\% bila kadar telur $6 \mathrm{kUa} / \mathrm{L}$, susu $32 \mathrm{kUa} / \mathrm{L}$, kacang $15 \mathrm{kUa} / \mathrm{L}$ dan ikan $20 \mathrm{kUa} / \mathrm{L}$. 
e. Kadar histamin yang dilepaskan basofil dan sel mast dapat diukur tetapi hasilnya tidak lebih sensitif daripada uji kulit.

f. Pemeriksaan kadar IgE spesifik tali pusat bayi baru lahir dapat menentukan derajat atopi bayi, bila kadar IgE spesifik tali pusat bayi terhadap susu sapi tinggi berarti telah terjadi sensitisasi intrauterin.

\section{Penatalaksanaan}

Setelah diagnosis alergi makanan ditegakkan, maka eliminasi makanan harus dilakukan dengan ketat. Pada penelitian terhadap 400 orang anak dengan alergi makanan, 2/3 nya alergi terhadap 1 macam makanan saja dan hanya $9 \%$ alergi terhadap lebih dari 5 macam makanan. Reaksi alergi makanan umumnya sangat spesifik untuk 1 jenis makanan, sehingga tidak perlu menghindarkan semua makanan yang termasuk golongan botanik yang sama. Penghindaran yang ketat harus dilakukan juga oleh keluarga pasien dalam menghindarkan serta membantu untuk mencarikan makanan pengganti sehingga terpenuhi makanan yang rasanya enak dan disukai anak. Mengetahui dengan pasti makanan yang akan diberikan untuk anak seperti membaca semua label makanan yang tercantum pada botol atau kaleng apakah mengandung produk dari

Tabel 2. Bahan yang Mengandung Protein Susu Sapi

\begin{tabular}{lll}
\hline Mentega & Keju cottage & Lactoglobulin \\
Buttermilk & Hydrolysae casein & Lactose \\
Casein & Hydrolysate protein susu & Lactulose \\
Keju & Susu kambing & Susu sapi bubuk \\
Cream & Lactalbumin & Cream asam \\
& Yoghurt & Whey \\
\hline
\end{tabular}

Tabel 3. Bahan Makanan yang Mengandung Kacang Kedele

\begin{tabular}{ll}
\hline Kacang kedele Miso & Hidrolisat soya protein \\
Saus soya & Penyedap alamiah \\
Tempe & \\
Tahu & \\
\hline
\end{tabular}

makanan yang harus dihindarkan. Seperti produk dari susu sapi (casein, whey, lactoglobulin, dan lain-lain). Pada Tabel 2,3,4, dan 5 dapat dilihat daftar makanan yang mengandung susu sapi, kedele, telur dan kacang.

\section{Pengobatan pada reaksi anafilaksis yang disebabkan makanan}

- Penghentian makanan tersangka.

- Epinephrin 0,01 mg/kg dalam larutan 1:1000 diberikan subkutan, dapat diulang setelah 10-15 menit, dan dirawat di ruang gawat darurat.

- Antihistamin parenteral.

- Kortikosteroid parenteral.

- Diawasi minimal selama 4 jam setelah syok dapat diatasi.

\section{Perjalanan Alamiah Alergi Makanan}

Alergi makanan sering terjadi pada usia tahun pertama dari kehidupan. Dua pertiga dari pasien akan toleran setelah menghindarkan makanan selama 1-2 tahun. Delapan puluh-sembilan persen anak dengan alergi susu sapi akan toleran pada usia sekitar 2-3 tahun. Anak yang mempunyai awitan alergi makanan pada usia lebih tua, sifat toleran akan sulit tercapai seperti pada alergi kacang, tree nut, dan ikan laut. ${ }^{3}$ Dilaporkan bahwa pasien alergi susu sapi akan menjadi asma (40\%), rinitis alergi (40\%) dan dermatitis atopi (20\%) di kemudian hari.

Tabel 4. Bahan Makanan yang Mengandung Protein Telur

$\begin{array}{ll}\text { Albumin } & \text { Kuning telur } \\ \text { Telur } & \text { Mayones } \\ \text { Pengganti susu } & \text { Ovalbumin } \\ \text { Putih telur } & \text { Ovomukoid }\end{array}$

Tabel 5. Bahan Makanan yang Mengandung Protein Kacang

\begin{tabular}{ll}
\hline Minyak kacang & Permen \\
Kacang tanah & Coklat \\
Mixed nuts & Cookies
\end{tabular}

Peanut butter

Peanut flour

Dikutip dari Burks WA, $1998^{11}$ 
Dianjurkan untuk melakukan rechallenge selang 1-3 tahun terhadap susu sapi, telur, gandum. Uji kulit dan pemeriksaan RAST akan tetap memberikan hasil positif walaupun sudah terjadi toleransi .

\section{Kesimpulan}

- Alergi makanan bukan didasari reaksi hipersensitivitas tipe I saja.

- Setelah diagnosis alergi makanan ditegakkan, pengobatannya adalah eliminasi ketat. Penghindaran suatu jenis makanan harus diperhitungkan kerugiannya terutama pada anak yang memerlukan makanan tersebut untuk pertumbuhan dan perkembangan. Haruslah diganti dengan bahan lain yang sama atau hampir sama nilai kalori dan nutriennya, serta penerangan yang baik diberikan kepada orang tua dan anak, dan seorang ahli gizi anak harus diikut sertakan untuk menghindarkan terjadinya gisi kurang. Penerangan yang jelas mengenai makanan yang harus dihindarkan dan makanan yang diperbolehkan harus jelas tertulis, dan selalu membaca terlebih dulu daftar isi makanan siap pakai dari kaleng/ botol. Sebagian alergi makanan pada anak akan menghilang dengan bertambahnya umur, kecuali untuk beberapa jenis makanan seperti kacang, ikan dan tree nuts.

- Gejala klinik terhadap 1 macam alergen makanan adalah spesifik. Jarang terjadi alergi terhadap beberapa macam alergen dalam satu famili botanik atau dalam satu jenis spesies binatang, sehingga penghindaran makanan hanya terhadap makanan yang sudah terbukti dengan pasti dengan cara eliminasi, akan memberikan perbaikan secara klinis. Sampai sekarang mekanisme imunopatologi alergi makanan belum jelas. Sekarang para ahli sedang meneliti sifat karateristik masing masing alergen dan patogenesis alergi makanan.

\section{Daftar Pustaka}

1. Bock SA. Prospective appraisal of complaints of adverse reaction to foods in children during the first 3 years of life. Pediatrics 1987; 79:683-8.

2. Burks Wesley A. Childhood food allergy. Immunol and Allergy Clin North Amer 1999; 19:397-407.

3. Sampson HA. Food allergy. JAMA 1997; 278:1888-94.

4. Siregar P Sjawitri. Faktor atopi dan asma bronkial pada anak. Dipresentasikan pada simposium alergi saluran napas pada anak informasi terkini. Jakarta, Oktober 1999.

5. Siregar P Sjawitri, Ida Mardiati, Akib Arwin. Cows milk allergy. Paediatr Indones 1999; 39:83-7.

6. Bruno LB. Prophylaxis of cow's milk allergy. Pediatr Allergy Immunol 1997: 8 (suppl 10): 11-5.

7. Hill DJ, Hasking CS. Emerging disease profiles in infants and young children with food allergy. Pediatr Allergy Immunol 1997: 8 (suppl 10): 21-26.

8. Broadbent JB. Diagnosis and management of food hypersensitivity. Immunol and Allergy Clin North Amer 1999; 19:463-77.

9. Bock SA, Lee W, Remigio L, dkk,. Studies of hypersensitivity reactions to food in infants and children. J Allergy Clin Immunol 1983; 71:473-80.

10. Borkowski TA, Eigenmann PA, Sicherer SH, dkk,. Prevalence of IgE-mediaated food allergy among children with atopic dermatitis. J Allergy Clin Immunol 1998; 101:s241.

11. Burks AW, James JM, Hiegel A, dkk,. Atopic dermatitis and food hypersensitivity reactions. J Pediatr 1998; 132:132-6.

12. Siregar P Sjawitri, Bambang Madiyono, Amar W Adisasmito. Risk factors of respiratory allergy among children with atopic dermatitis. Paediatr Indones 1999; 39:134-44.

13. Iacono G, Carroccio A, Cavataio F, dkk,. Chronic constipation as symptom of cow milk allergy. J Pediatr 1995; 126:34-9.

14. Onorato J, Merland N, Terral C, dkk,. Placebo controlled double-blind food challenges in asthma. J Allergy Clin Immunol 1986; 78:1139-49.

15. Yungyinger JW, Sweeney KG, Sturner WQ, dkk,. Fatal food-induced anaphylaxis. JAMA 1988; 260:1450-2.

16. Bock SA, Sampson HA. Food allergy in infancy. J Pediatr Clin North Am 1994; 41:1047-67.

17. Sampson HA, Albergo R. Comparison of results of skin tests, RAST, and double-blind placebo-controlled food chaallenges in children with atopic dermatitis. J Allergy Clin Immunol 1984; 74:26-33. 